\title{
Who Calls the Shots? \\ The Insiders and Outsiders of (Un)just Participation in Slovenian Elementary Schools
}

\author{
Urban Boljka, Social Protection Institute of the Republic of Slovenia \\ Jasmina Rosič, School for Mass Communication Research at the KU Leuven \\ Tamara Narat, Social Protection Institute of Republic of Slovenia
}

\section{Introduction}

7 he participation of children in the school setting is an increasingly relevant research topic. In the last few years, the literature on it

1 has expanded from advocacy texts, critiques and descriptions of the different approaches to both empirical (Hart, 1992; Lansdown, 200I) and theoretical debates (Kodele, 2017; Marovič, 2017; Mithans, 2017; Rutar, 2013).

Child participation has become an important research topic not only because it constitutes part of the Convention on the Right of the Child and introduces children to active citizenship (in practice), but also with respect to assessing the fairness of the education system in which this very participation occurs.

In this article, we focus on the last point. We are interested in assessing the Slovenian education system in terms of its readiness to ensure that all children have the right to be heard and the right to participate in decision-making process in schools. Child participation is here more particularly understood in terms of children being: a) provided with information about their right to participate in decision-making in elementary schools; and b) children being represented in forums, including through their own organisations, on school, local, regional and national governance levels ${ }^{1}$.

I The definition of participation was influenced by the Council of Europe's project Implementation of Council of Europe Child Participation Assessment Tool. Focus groups with children have been conducted as part of this project. 
We pose a twofold question, namely whether the education system and more specifically the participation arrangements as part of it are designed (or are able) to support and encourage the participation of different groups of children and which groups tend to be the most deprivileged in terms of their participation opportunities and outcomes.

We tackle these questions using the theoretical language of egalitarian liberalism (Rawls, 1971, 1999) and the recognition approach (Fraser, 200I) (partly developed on its criticism). This is an important contribution to the literature on child participation as the aspects of what just participation in elementary schools entails are rarely tackled. We start out by briefly describing theoretical approaches, building a solid basis for considering the above research question. The methods used in the analysis are then presented. The thematic analysis of is focus groups with is7 elementary school children was used (more details in the methods section). The analysis attempts to connect the theoretical approaches and practical arrangements for child participation in elementary schools. Here the emphasis is placed on the real experiences of various groups of children. The analysis concentrates on comparing the two types of focus groups, the first with either children from disadvantaged socio-economic and cultural backgrounds, and/or with behavioural, emotional and learning difficulties and the second being focus groups with children randomly chosen by elementary schools across Slovenia ${ }^{2}$. The findings are presented in the last part.

\section{Theoretical approaches to assessing the fairness of participation arrangements in elementary schools in Slovenia through the child participation lens}

Discussions on how to create a school environment which would be just for all and how to assess its fairness are often based on various theories of justice. These theories find their rational in different principles of just distribution (see e.g., Brighouse 2000, 2002; Curren, 1995; Gutman and Callan, 1997; Kodelja, 2006) $)^{3}$ most prominently developed in Rawls' (1971, 1999) theory of justice which can be understood within broader ideas of egalitarian liberalism. In Rawls' most famous work $A$ Theory of Justice, Rawls (197I) does not deal with issues of justice in education in great depth, they are merely mentioned. Rawls understands justice in

2 In the article, we also refer to the first group of children as vulnerable children or disadvantaged children and the second group as children from the general population.

This not only applies to scientific analyses, but to strategic documents such as the White Paper on Education in the Republic of Slovenia (20II) which adopted the principle of distribution or the Rawlsian approach as the starting point for thinking about a just education. 
broader terms, namely at the level of the social system. He argues for a just society which must ensure the distribution of primary goods (such as freedom and opportunity, income, wealth and the basis of self-esteem), and social institutions (e.g. legal protection of freedom of thought and freedom of conscience, competitive markets, private ownership of productive assets, a monogamous family) which (if provided) ensure a just society. Although Rawls (197I) does not pay much attention to education, the education system can surely be considered as one social institution whose practices influence the distribution of the individual's opportunities. As such, Rawls' ideas also find their place in academic attempts to assess the fairness of education systems on the systemic level as well as the micro level (for instance, assessing the practices of teachers) (Kodelja, 2006).

The basis of Rawls' (197I) formulation of justice lies in a special conception of justice; namely, justice as fairness whose two underlying principles ensure a just and moral society:

I. The Greatest Equal Liberty Principle. Each person is to have an equal right to the most extensive total system of equal basic liberties compatible with a similar system of liberty for all. The latter relates mainly to a range of primary social goods required to obtain the status of a free and equal citizen therefore ensuring the inclusion into mutually cooperating society throughout the individual's life. This principle does not, however, relate to natural primary goods such as health, intelligence, natural talents, etc. (Van Parijs, 2003, pp. 210-2II)

The second principle argues that, despite inequalities forming part of the society, a society may be considered to be just if such inequalities are arranged in line with:

2. The Difference Principle. This means that the social and economic inequalities are to be arranged so that they are both:

a) to the greatest benefit of the least advantaged, consistent with the just savings principle; and

b) attached to offices and positions open to all under conditions of fair equality of opportunity. (Rawls, 1971, pp. 302-303)

The principles are arranged in such a way as to give lexical priority for I over 2(b) and 2(a). In building a just society, Rawls (197I) is primarily interested in how to improve the initial opportunities of individuals and not whether the maximisation of opportunities results in more equal outcomes for these individuals. The subject of legitimate redistribution ${ }^{4}$ is 
those opportunities linked to social class and family background that allow the individual to attain advantaged positions in society. On the contrary, the post-distribution voluntary choices of individuals cannot be considered a legitimate subject of redistribution. Such inequalities are part of what, according to Rawls, is part of a just society since they have been caused by the voluntary actions and choices of each individual (Van Parijs, 2003, 2013).

Rawls' ideas of a just society can be translated into the education field by understanding equality of educational opportunities as a prerequisite for the individual's right to be educated and thereby to succeed in life. The White Paper on Education in the Republic of Slovenia (20II, p. I4), the key national strategic document in this field, defines a just education system as a system which allows inequalities in educational outcomes so long as everyone is entitled to the same opportunities and all inequalities are the consequence of free choice, different levels of ability, effort and risks. Such orientation may be considered to be in line with Rawls' difference principle. The assessment of whether the education system is just is here blatantly made a matter of whether children are in control of several factors that usually can be considered to be the cause of social inequalities - factors like gender, social class, ethnic origin that depend on sheer luck, as children cannot choose them. The logic here dictates that a just educational environment should therefore place considerable emphasis on reducing these inequalities and gaps in educational outcomes as they are caused by these factors, by brut luck (Brighouse, 201I). As described in the White Paper on Education (20II), the education system in Slovenia focuses on maximising the opportunities and providing equal opportunities for all. In an ideal scenario, this would reduce the gaps between the educational attainments of pupils with different social and cultural backgrounds. That part of the document which concentrates on justice states that:

This would be achieved using the policy of positive discrimination focusing on children from socially and culturally disadvantaged backgrounds with the aim of providing universally accessible education on one hand but also individualization of the school system in terms of maximising the opportunities for obtaining quality education and development of each student/pupil into an autonomous individual, inclusion of children with special needs etc. (White Paper on Education, 20II, pp. I4-I5).

include having fewer native abilities or less willingness to cultivate them than others. For instance, in an educational setting, this principle may support educational measures that close the attainment gap between the naturally talented rich and the naturally talented poor. 
In spite of ideas close to egalitarian liberalism (Rawls, 197I) being popular when thinking about designing more just education systems, there seems to be several limitations while translating and operationalising these ideas into practical educational policy and their application to the school environment. Here are some examples:

The question arises as to the practical applicability of the difference principle. The principle states that the unequal distribution of primary social goods is fair insofar as it benefits the most disadvantaged. It is difficult to imagine how the most disadvantaged pupils with the worst educational outcomes would benefit in any way from a system in which the least disadvantaged would have their learning outcomes maximised (Harel Ben-Shahar, 2015, p. 5), which would be Rawls' (197I) idea of a just education according to the difference principle.

- Another issue emerges with the inclusion of personal risky choices in the notion of social justice because it is very difficult to distinguish the choices an individual is responsible for and the choices subject to objective circumstances that have influenced the individual's social position. According to Andersen (1999), in practice this would result in the legitimisation of processes leading to a division between citizens who make responsible choices and those who do not. Similar emphasis is also given by Harel Ben-Shahar (2015, p. 7, p. 9) when providing the example of capabilities and effort:

- Harel Ben-Shahar (2015, p. 7) disagrees with the static and constant notion of talents and capabilities which Rawls (1971) believes are part of the natural primary resources and as such are not subject to redistribution. She argues that both can be increased through upbringing as well as education.

Differences in effort and aspirations are often seen as a tool for justifying differences in children's learning outcomes because both effort and aspirations are viewed as assets over which individuals have control. Harel Ben-Shahar (2015, p. 9), on the contrary, claims that effort can be understood as an asset over which individuals have no control: a) it can be understood as a natural ability dependent on the ability to concentrate, on diligence, emotional strength and other components and not as a personal choice; $b$ ) there is a correlation between deprivileged groups of children, the influence of cultural capital and the type of community in which they are growing up in and which lower motivation to study - these are again factors outside the 
individual's control and should therefore not (in a just education system) have an influence over learning outcomes.

A just school system should hence expand the list of items in the focus of redistribution by adding talents and abilities. Further, more lenience and greater understanding should be shown while rewarding/punishing motivation or effort because these are the key elements of learning outcomes.

\section{The notion of justice and child participation in elementary schools}

The redistribution approach seems to be a limited basis for thoroughly assessing whether (and to what level) the design of child participation within schools may be considered to be just. There are at least two reasons for this argument. First, the redistribution approach mainly considers the educational attainment and learning outcomes of children and leaves little room for exploring child participation. In contexts other than theoretical debates on justice in education systems, the assessment and evaluations of the fairness of education systems typically rely on indicators measuring the learning gaps between various groups of children, differences in the learning outcomes of children from different ethnic backgrounds, the influence of different regions and countries' contexts, differences (and factors) defining the expectations and aspirations of children, the share of early school leavers etc. (see e.g. PISA OECD, 2020). Unjust differences in the participation and active inclusion of children in participatory processes, which are very important for the education and school lives of children, are therefore set aside. This is surprising as Rawls' notion of a just society mentions morality' as essential for the individual's autonomy ${ }^{6}-$ both

It is very common for morality to be part of discussions about a just society, but it is rarely considered as an important concept when talking about the participation of children. Mayall (2000) is one of the first authors to introduce a link between the participation of children and their moral status. She argues that so long as society does not recognise children as moral actors (meaning they are able to make a moral judgment based on their awareness of a particular situation and encounter with themes like fairness and distribution), the possibilities for them to participate in decisions important for their lives will remain limited.

Personal autonomy is, according to Brighouse (2002), one of the most important principles (besides educational equality) promoted by egalitarian liberalism. Every child should have an opportunity to become an autonomous person, a person capable of rational reflection of his/her beliefs and commitments, which is fundamental for achieving individual well-being. The educators' role is important here: "Educators have a duty to facilitate autonomy - to make sure that children have a real opportunity to become autonomous - rather than to promote it" (Brighouse, 2002, p. 184). Brighouse further argues the importance of rational reflection on decisions on how to utilise the set of basic liberties society guarantees: "It is their right, and their obligation, to use these liberties responsibly, both for their own benefit and for the good of others. To do this they need to weigh reasons and 
aspects should thus be key when assessing the level of child participation (Mayall, 2000). Still, Rawls does not mention participation directly.

Second, the question of what a just society entails stays limited to "the question of distributivity and omits the issues of representativeness, identity and difference", which are key concepts of the recognition approach (Fraser, 1995, 2000, 2001, 2003). Those are the vital concepts while analysing participation and are especially important for collective participation. They could provide solid guidance for assessing whether the participation of minority groups with their own identity is just. As we show later, their participation opportunities are limited; their interests are at best being represented by others. Following this, we argue, similarly to Fraser (2003, p. 5), that only the combination and commitment to both approaches can result in a just society, a just education system and just child participation in schools.

\section{The recognition approach}

The recognition approach advocated by Fraser (1995, 2000, 2001, 2003) is therefore also adopted in our discussion of justice in education as well as the just participation of children from disadvantaged socio-economic and cultural backgrounds and children with behavioural, emotional and learning difficulties. Three reasons explain why this approach is better suited to our analysis. First, it is directly related to the need for people to assume an active role, to be engaged and participate as a condition for a just organisation of society. Fraser (200I) argues that a new field of social justice must be established whose need is made urgent by the growing differentiation of postmodern societies. There is a corresponding need to recognise different group identities and differences of individual social groups within their struggle for recognition. Participation is directly mentioned in the recognition approach in the principle of parity of participation. This principle can be adopted for this article's purpose, that is, to assess whether participation in the Slovenian education system is just. In general, this principle stipulates that: a) the distribution of material assets enables the individual to be independent and have a voice; and $b$ ) the institutional arrangement fosters different patterns of cultural value, which ensures equal respect and equality of opportunity for all individuals (Fraser, 200I, p. 6).

Second, unlike the theories of distributive justice, the recognition approach does not overlook the questions of cultural aspects of injustices and hence the importance of politics of recognition. It takes one

evidence for different courses of action: the capacity for rational reflection is an essential tool for this" (Brighouse, 2002, p. 184). 
important step beyond the theories of distributive justice. While the redistribution approach uses compensation as a tool for increasing the opportunities of those in the least favourable position, the recognition approach reminds us that these increased opportunities can (in some cases) remain unrealised. Namely, individuals who are faced with adversities of status differentiation and status discrimination often fail to use increased opportunities.

Third, Fraser (2003, p. I5) coins the term bivalent collectivities to explain why social justice must inevitably entail both socio-economic as well as cultural dimensions. Bivalent collectivity represents a social group disadvantaged both in terms of its socio-economic and cultural sense, as is the case with our target group, and neither sense can be limited to the effects of only one because they are intertwined and work simultaneously ${ }^{7}$.

The recipe for making contemporary society more just might therefore lie in the recognition of what must entail the re-evaluation of disrespected and unrecognised social groups, their cultural production and their differentness. This cannot be achieved without re-evaluating the symbolic social order by dissecting the conditions which uphold the current status differentiation, in turn raising questions of power and privilege. For example, one way to deconstruct the privileged social dimensions is, according to Wang's study of school principals' perception of social justice (2016, p. I2), to "raise the consciousness of dominant group about its privilege over the less advantaged, and openly discuss the interplay between power and control".

As mentioned, this article combines both approaches (redistributive and recognition) to assess whether the existing arrangements and practices of child participation in elementary schools in Slovenia are just in terms of equal opportunities for vulnerable groups of children. The redistribution approach principles will allow us to identify sources needed for child participation in school and indicate what are, according to the focus group participants, the preconditions for participation to be just for all. The conditions for all children to participate are merely one aspect of just participation, while the other one is to reduce inequalities in participation outcomes. Therefore, a more complex analysis is needed, one that goes beyond analysing only opportunities to participate. Here, the recognition approach is better suited to assessing whether the participation arrangements are just as it concentrates not only on the formal requirements

7 A typical example of bivalent collectivity is gender. Namely, gender inequalities can be partly attributed to economic inequalities, partly to the society and to the culture. Other examples of bivalent collectivities are race, class, sexual orientation, and ethnicity (Robeyns, 2003, p. 3). 
for just participation, but also on the concepts of power, privilege and respect, which shed light on the obstacles faced by vulnerable groups of children and thus on inequalities in participation outcomes.

\section{Methods}

In order to answer our research question, we adopted a qualitative research approach. In total, is focus groups with 157 children were organised (as part of the project Implementation of Council of Europe Child Participation Assessment Tool (Council of Europe, 2016)), I2 with children from the so-called general population of children from elementary schools and 3 with children who were invited to participate by NGOs working with and for vulnerable children (especially by advocating for their rights, empowering, supporting and encouraging them to address issues in their lives whether this involves a quarrel at home, a notice of expulsion, bad grades or being in trouble with the police).

\section{Participants}

Elementary schools which participated came from different statistical regions ( 9 out of I2), from rural and urban areas (as shown in Table I). Despite efforts to ensure balanced representations according to statistical regions, more focus groups were conducted in the Central Slovenia ( 7 in the capital city of Ljubljana). This can be justified by the concentration of the population in the Central Slovenia and by the diversity of schools in Ljubljana's districts. The number of focus groups in the sample was determined based on saturation. When topics began to repeat, further data collection became redundant (Hennink et al., 2019; Glaser and Strauss, 1967; O'Reilly and Parker, 20I2). One focus group per participating school was conducted. The teachers (or other contact persons) did not receive any specific and formal instructions for the selection of children but only asked to select approximately io children aged io to 14 years. They were informally encouraged not to select only high performers but a cross section of their school population, although this was not always the case (see Chapter 6). The number of participating children per focus group varied from 7 to 14 . The selection of children was gender-balanced and children came from different age groups, yet most were ro- to I 4-years old. One focus group with younger children ( $6-9$ years old) was conducted. Each focus group lasted two school hours (I.5 h), with a 5 -minute break. The focus groups were held between 20 September and 4 November 2019.

While selecting the sample of focus groups with vulnerable children, we tried to cover as many possible different categories of children 


\begin{tabular}{|c|c|c|c|c|c|c|c|}
\hline $\begin{array}{c}\text { Elementary } \\
\text { school }\end{array}$ & $\begin{array}{c}\text { Specific } \\
\text { background }\end{array}$ & Statistical region & $\begin{array}{l}\text { Children's } \\
\text { residence }\end{array}$ & $\begin{array}{c}\text { No. of } \\
\text { participants }\end{array}$ & Age & Date & Duration \\
\hline $\begin{array}{l}\text { Elementary } \\
\text { school I }\end{array}$ & & $\begin{array}{l}\text { Mura } \\
\text { [Pomurska regija] } \\
\text { (north-east) }\end{array}$ & Village & 9 & $10-14$ & 20.09 .2019 & \\
\hline $\begin{array}{l}\text { Elementary } \\
\text { school } 2\end{array}$ & & $\begin{array}{l}\text { Savinja } \\
{[\text { Savinjska }]} \\
\text { (east) }\end{array}$ & City, village & 9 & $10-14$ & 24.09 .2019 & \\
\hline $\begin{array}{l}\text { Elementary } \\
\text { school }_{3}\end{array}$ & & $\begin{array}{l}\text { Drava } \\
\text { [Podravska regija] } \\
\text { (east) }\end{array}$ & Large city & 9 & II -15 & 30.09 .2019 & \\
\hline $\begin{array}{l}\text { Elementary } \\
\text { school } 4\end{array}$ & & $\begin{array}{l}\text { Lower Sava } \\
{[\text { Posavska regija] }} \\
\text { (east) }\end{array}$ & City, village & 13 & $12-14$ & 16.10 .2019 & \\
\hline $\begin{array}{l}\text { Elementary } \\
\text { school } 5\end{array}$ & & $\begin{array}{l}\text { Upper Carniola } \\
\text { [Gorenjska regija] } \\
\text { (north-west) }\end{array}$ & City & I2 & $\mathrm{II}-\mathrm{I} 4$ & 4.11 .2019 & \\
\hline $\begin{array}{l}\text { Elementary } \\
\text { school } 6\end{array}$ & / & $\begin{array}{l}\text { Littoral-Inner } \\
\text { Carniola } \\
\text { [Primorsko- } \\
\text { notranjska] (west) }\end{array}$ & City, village & 13 & $12-14$ & 18.10 .2019 & $\begin{array}{l}2 \text { school } \\
\text { hours } \\
\text { (I.5 h) }\end{array}$ \\
\hline $\begin{array}{l}\text { Elementary } \\
\text { school } 7\end{array}$ & & $\begin{array}{l}\text { Southeast Slovenia } \\
\text { [Jugovzhodna] } \\
\text { (south-east) }\end{array}$ & City,village & 14 & $\mathrm{II}-\mathrm{I} 4$ & 23.10 .2019 & \\
\hline $\begin{array}{l}\text { Elementary } \\
\text { school } 8\end{array}$ & & \multirow{4}{*}{$\begin{array}{l}\text { Central Slovenia } \\
\text { [Osrednjeslovenska] } \\
\text { (central) }\end{array}$} & \multirow{4}{*}{ Large city } & 12 & $10-14$ & 22.10 .2019 & \\
\hline $\begin{array}{l}\text { Elementary } \\
\text { school } 9\end{array}$ & & & & IO & $\mathrm{II}-\mathrm{I} 4$ & 21.10 .2019 & \\
\hline $\begin{array}{l}\text { Elementary } \\
\text { school ro }\end{array}$ & & & & II & $12-14$ & 9.10 .2019 & \\
\hline $\begin{array}{l}\text { Elementary } \\
\text { school II }\end{array}$ & & & & 9 & $12-14$ & 24.10 .2019 & \\
\hline $\begin{array}{l}\text { Elementary } \\
\text { school I2 }\end{array}$ & & $\begin{array}{l}\text { Gorizia } \\
\text { [Goriška regija] } \\
\text { (north-west) }\end{array}$ & Village & 7 & $6-9$ & 10.10 .2019 & \\
\hline $\mathrm{NGO}_{\mathrm{I}}$ & $\begin{array}{l}\text { Children with } \\
\text { either disad- } \\
\text { vantaged socio- }\end{array}$ & \multirow{3}{*}{$\begin{array}{l}\text { Central Slovenia } \\
\text { [Osrednjeslovenska] } \\
\text { (central) }\end{array}$} & \multirow[b]{2}{*}{ Large city } & 10 & $13-15$ & $\begin{array}{c}9.10 .2019 \\
10.10 .2019\end{array}$ & $\begin{array}{l}4 \text { school } \\
\text { hours } \\
(3 \mathrm{~h})\end{array}$ \\
\hline $\mathrm{NGO}_{2}$ & $\begin{array}{l}\text {-economic and } \\
\text { cultural back- } \\
\text { ground and/ } \\
\text { or behaviou- } \\
\text { ral, emotional } \\
\text { and learning } \\
\text { difficulties }\end{array}$ & & & 10 & $11-17$ & 13.10 .2019 & $\begin{array}{l}2 \text { school } \\
\text { hours } \\
\text { (I.5h) }\end{array}$ \\
\hline $\mathrm{NGO}_{3}$ & $\begin{array}{l}\text { Children's } \\
\text { Parliament } \\
\text { participants }\end{array}$ & & $\begin{array}{l}\text { Large city, } \\
\text { village }\end{array}$ & 9 & $12-14$ & 27.09 .2019 & $\begin{array}{l}2 \text { school } \\
\text { hours } \\
\text { (I.5h) }\end{array}$ \\
\hline Total & & & & 157 & $6-17$ & & \\
\hline
\end{tabular}

who might be at higher risk of being excluded from the exercise to participate (e.g. younger children, children living in families with lower socio-economic status, cultural background, those from ethnic minorities, children with disabilities, learning difficulties, children in institutions) 
and, on the other side, the ones who participate the most. To accomplish this, we contacted NGOs working with and for children and youth and four focus groups with the NGOs' assistance were performed. Two focus groups were with children with either a disadvantaged socio-economic and cultural background and/or behavioural, emotional and learning difficulties (here one participant older than I4 participated; in her answers, she reflected on her experiences of participation in elementary school) and one with children participants in the project Children's Parliament.

\section{The measurement instrument}

In order to conduct the focus groups, we developed semi-structured, child-friendly question guidelines which followed the logic of the Child Participation Assessment Tool's indicators.

The guidelines assess several areas important to children's lives. The topics discussed with the children were: (I) the provision of information regarding their right to participate; (2) children's representation in children's forums; (3) child-targeted feedback mechanisms on local services; (4) the availability of child-friendly, individual complaint procedures; and (5) an independent children's rights institution. The article deals with the first two topics and the proposed guideline questions for these two topics are thus enclosed in Appendix I.

\section{Procedure}

Organising the focus groups included sending out invitations to schools and NGOs, communication with schools and NGOs (participants, venues, protocols etc.), arranging formalities with regard to data confidentiality, parents' permissions, small rewards for children (as recommended by Fargas Malet et al., 2010) and the development of child-friendly communication tools (emojis) (as suggested by Fargas Malet et al., 2010; Hill, 1997; Veale, 2005). The two focus groups with children with either a disadvantaged socio-economic and cultural background and/or behavioural, emotional and learning difficulties were performed by the NGOs themselves (after short training of the facilitators by our team), while the others were performed by the authors. All sessions were audio recorded (with the children's consent) and transcribed. Anonymisation was ensured by asking the children to come up with nicknames for use during the focus groups and by anonymising the names of the schools and NGOs.

\section{Data analysis}

The data were analysed by MAXQDA, a coding software package. The thematic analysis was carried out in a deductive way (Boyatzis, 1998; Braun 
and Clarke, 2006; Hayes, 1997) and the data were analysed on the basis of systematic coding (breaking down the data to the coding system to identify relevant patterns), following the approach suggested by Saldana (2012). The coding system followed the logic of the Child Participation Assessment Tool's indicators and was organised hierarchically over three levels. It consists of seven main codes (first level) which summarise the main focus group topics: (I) co-decision-making in the family environment; (2) children's rights to be informed about the right to participate; (3) informedness about the right to participate and child/human rights; (4) forums for children; (5) co-decision-making in the local community; (6) an ombudsperson; (7) child-friendly, individual complaints procedures, with 24 subcodes (second level) which further categorise the main codes, and 27 subcodes (third level) which further detail the 24 subcodes of the second level. The analysis included almost 5,000 coded segments organised in the coding system.

\section{Analysis of the determinants for equal participation in school}

Are children informed about the right to participate and can all children equally exercise their right to participate in school? In general, the focus group analysis shows that the children feel they are provided with the information about their right to participate and that this information is mainly given in the school setting. Some children who participated in the focus groups also reported they would not have been informed about their rights at all had it not been for the school. Besides school, other important sources of information are parents and other members of their families, some children receive information from the media. As we continued with conversations about their views on the equality of opportunities to be informed about their rights or to be actively involved in participation practices, several children were convinced (as they follow the same curriculum in the public school system) that all children in Slovenia are equally informed about their rights and can equally participate in school (participation) activities (e.g. running for class president). If we judge the education system solely by these merits and only consider Rawls' (197I) theory of justice, the Slovenian education system and its ability to inform children about their right to participate may be described as being in line with Rawls' first principle - the greatest equal liberty. Namely, some focus group participants argue that the right to be informed about child participation is fully ensured.

Yet, a different side to the story is revealed by the group of children who had either a disadvantaged socio-economic and cultural background 
and/or behavioural, emotional and learning difficulties. This group generally noticed inequalities in opportunities in informedness.

The child focus group analysis makes it evident that, as defined by Fraser (200I), the education system and arrangement of participation perpetuates the differentiation of status. We can observe several factors at play which prevent equal child participation in school. What are they? One of them is, according to the participants, the age. Older children are generally better informed than younger ones. Another reason behind this is teachers' inability to provide age-adapted content on child participation.

Basically, technically speaking you are still developing and later on you look at things differently. For instance, you would use a completely different way to explain what participation is to a first-grader than to someone who is in the third year. (Jasna, I4 years, NGO I)

Participants also felt that younger children are not only less informed but also have fewer practical opportunities provided to them to participate (for instance in the school parliament). Elementary school forums (the school communities and/or the Children's Parliament) include a limited number of children who are indeed generally older (the last triad of elementary school).

According to some children, the level of informedness is also determined by one's region of residence, with many believing that children from the central regions of Slovenia are better informed about their right to participate, and that participation is also determined by the urban vs. rural divide, albeit opinions are divided here. The majority believe that children from urban areas are better informed than their counterparts from rural areas, claiming the greater economic development and accessibility of information in urban areas as the reasons.

If we take Ljubljana and one village for example, then those from Ljubljana are at least twice as informed as those from the villages. They are remote and don't even know what is going on. (King Konk, 13 years, NGO 3)

The rationalisation of these arguments is rooted in the perception the participants express, namely, that the topics of human rights and child participation are more important in urban settings where people tend to be more individualistic and willing to express their opinions. In rural areas, the information flow is slower and so too is the pace of life, some participants believe. 
I don't know, they probably really know less, those children living in the village, because they probably don't look in depth into these topics. They're probably talking to each other, but that's not it. Also, the information flow is slower there. And they do not emphasise their own opinion so much. (Pia, I 4 years, elementary school 5 )

Still, in contrast, some believe that children living in rural areas, in villages are better informed because fewer people live there, information travels faster and the voice of the individual is more easily heard. Those children also think that because school classes tend to be smaller in the countryside, information travels faster and school subjects dealing with participation are discussed in greater depth than in the cities.

In my opinion, for example, in larger cities where there are more people, it is harder for everyone to express their opinion because there are too many of them, but in smaller villages you can express your opinion because there are fewer people and it takes less time. (Nodi, I3 years, NGO I)

Besides the age and place of residence, another important factor affecting the status differentiation in terms of informedness about children's rights and child participation is the parents' socio-economic, cultural and educational status. Several focus group participants believe that children from disadvantaged families exposed to the risk of poverty and facing social problems are usually also deprivileged in terms of being informed about their right to participate.

I don't know, maybe those who are the minority, or those who don't have enough money to go to this school, and they don't talk about it at all. (Ema, Ir years, elementary school 8).

Something similar can be claimed for children whose parents are less educated and for children with a migrant background.

Immigrants, let's say we have a lot of Albanian immigrants. They simply don't understand so much ... They don't know, I mean, they don't understand what kind of rights we have here in Slovenia because they can be different from where they are from, for example .... (Summer, I4 years, elementary school 7)

Another general observation indicating differences between children from the focus groups with a general population of children and the focus groups with vulnerable children is that vulnerable children are typically much more sensitive to inequalities based on their own experiences. They mentioned several situations when they were treated unfairly due to 
their migrant background and when their rights to participate were limited more than for other children.

For example, when Slovenian pupils are graded, they get asked three questions, they know nothing, they still get a 3 [good]. Or let me tell you... they answer one question correctly and get 5 [excellent]. But for us, not from Slovenia, we are up there in front of the whole class and get five questions, we answer four and a half questions correctly and we get I [fail]. He [the teacher] says you did not deserve to pass...I think this is not OK... that all these Slovenians get $5 s$ [excellent] and the rest of us worse grades.... (Isus-Vuk, I 4 years, $\mathrm{NGO}_{2}$ )

It seems to me that some teachers are unfair to people who are not pure Slovenians .... (Nodi, I3 years, NGO I)

It gets on my nerves because there is a lot of nationalism at schools .... (Janez, Is years, NGO I)

On the contrary, the participants from focus groups with a general population of children were usually children from families without any financial issues, with good educational attainment and excellent debating skills - schools typically choose the most eloquent and talkative children despite being instructed not to do so. Further, the comparison of the two groups in terms of the participants being articulated, eloquent, being able to express complex and/or abstract ideas reveals important differences in favour of the children from the focus groups with a general population. Similarly, differences between the two groups appear when comparing their understanding of child participation in schools, their perceptions of what can be achieved by it, and their view on entitlement to participate in the decision-making processes in schools. Here we can argue that children with either a disadvantaged socio-economic and cultural background and/or behavioural, emotional and learning difficulties are, to use the language of the recognition approach, a typical bivalent collectivity they face injustices in participation that are simultaneously traceable to the systemic arrangement of participation in school and the culture.

In terms of whether the children's views support the idea that all children have the same opportunity to be informed and to take part in the participation activities based on the education system providing them the opportunity to do so, the short answer is no. Here the just in child participation cannot be only guaranteed by distributing equal opportunities to all children and expecting that those in the most vulnerable position will miraculously seize these opportunities (as in Rawls' (197I) understanding of fair equality of opportunity), but to recognise and remove the obstacles 
to participation encountered by vulnerable children (as in Fraser's (200I, 2003) understanding of fair equality of opportunities under the recognition approach).

Another important angle of the children's insights into which factors influence the level of informedness about participation is the engagement of teachers and their way of presenting participation topics. Children believe that those who are taught by motivated teachers who use child-friendly language and innovative methods (like technology) to present the topics are better informed.

It depends on each individual, each teacher individually. (Khloe, I 4 years, elementary school 6)

And also, we are more interested in what is for example on the computers, videos, YouTube ... we are more familiar with that than with textbooks and books and newspapers and that. (Miha, 14 years, elementary school 6)

Moreover, vulnerable children often felt that the language used by teachers is too professional and demanding, meaning they cannot understand the teacher's explanation and wish they would use more child-friendly language.

Yes, with words that are better known to you, just like you would speak at home. Because teachers use technical terms every time when they explain things to you. Because you really don't know what they mean, you need to google things and then explain the term them to yourself and then you know. (Jasna, I 4 years, NGO I)

The children were convinced that if teachers are sensitive to the vulnerability of individuals, recognise their strengths and adapt their teaching approach to certain children's needs, this leads to greater informedness. This then increases their opportunities to participate.

Yes, it depends on the teachers, some of them just say something and nobody understands anything, because there are such technical terms and some really take the time and talk about it, so that we can understand. Yet, I had a bad experience in elementary school, and I didn't understand what she was saying. We were making just some posters and we were copying .... (Violica, I7 years, NGO I)

\section{Which group of children calls the shots?}

Child forums are some of the most frequently used child participation practices in schools (class community, school community, the Children's 
Parliament) (Boljka et al., 2019; Strehar, 20II). Which children are the most active in these activities and which factors influence their decision to become involved? This is, we argue, chiefly influenced by children's personality traits, their communication competencies, leadership skills and motivation to be involved, but also by school professionals who act as a gatekeepers favouring particular groups of children over others.

Even though some focus group participants claimed that the socio-economic or cultural background does not seem to be crucial (or better, that it should not be crucial) for the child to be selected as a class representative or forum participant and that what matters is (or better, should be) the child's motivation and ideas, the practice clearly shows that children who are more eloquent, who are actively involved in class and outside school activities, children with exemplary behaviour, and driven, independent, reliable, trusted and popular children among classmates and teachers are usually selected.

It doesn't matter how much money someone has or how much someone can afford. What matters are the ideas and willingness to stand up for everybody. (Vanaly, i3 years, elementary school 2)

If, on one side, the above characteristics make a child suitable for engaging in participation practices, what kind of personality traits or lack of competencies for participation prevent a child from being eligible for participation? The following discussion from a focus group in elementary school I provides an insight into this:

Moderator: But who wouldn't be suitable enough [to be chosen a class representative]?

Kai, I 4 years: For example, our classmate $\mathrm{XY}$, who for example is not ... (laughter)

Eva, 8 years: Once he was almost kicked out of school.

Kai: Once, he was almost held back.

Ana, 14 years: And argues with the teacher.

Nikki, I4 years old: Well, he's dyslexic.

Moderator: But, if someone is dyslexic, do you think one is less suitable to be the class president?

Ana: No, but one has to be a role model for others.

Eva: We wouldn't want someone who gets into all kinds of trouble to be the class president.

The discussion shows that some personal traits outside the control of children (being dyslexic) may prove (at least in the eyes of some pupils) to be the exact trait which prevents someone from becoming a class 
president. Despite this person having normatively the same chances as everyone else to become a candidate for class president, his chances look grim. Yet are the education system's practices such that they maximise his opportunities in participation terms?

The children generally think the school practices support the status quo. Children who are favoured to participate in child forums often have better opportunities and talents than other children and, in principle, come from families which are not socio-economically deprived. On the contrary, vulnerable children are not given the opportunity. From the perspective of assessing the fairness of child participation in school, what is worrying is that, even if they show interest and are motivated, this does not lead to their selection. And children are aware of this.

In our school, if I had been elected, the teacher would have said: 'Can you step down, so we can elect someone smarter?' This is what she said to me. Sometimes, the teachers degrade those with bad grades and favour those with $5 s$ (excellent). (Muhamed - Čačkalica, i3 years, $\mathrm{NGO}_{2}$ )

The above quote and many other children's thoughts expressed in the focus groups show that teachers play the key role in choosing the class and children's forums representatives. Commonly, teachers suggest the candidates, or select 'the most appropriate child' among the candidates. Quite often, (anonymised) voting takes place, yet the teacher confirms whether a pupil meets all of the mentioned 'suitability criteria' (eloquence, reliability, independency, good grades etc.) to be the class representative. Other pupils who do not match these criteria, even though they are motivated to participate as a class representative, are usually not selected.

We just... me and my friends we are not part of this process. The teacher just doesn't allow those of us who are more on the naughtier side to participate ... (laughter) ... So, we, the troublemakers, can't participate at all. The children who are obedient and more silent are always chosen. The teacher is just not democratic .... (Smajo - Alah, I4 years, NGO 2)

Following Rawls' (197I) theory of justice, we may argue that in practice vulnerable children are deprived of opportunities enjoyed by other children from the 'general' population. Having the same participation rights and subsequently their opportunities maximised by providing them with universal access does not lead to equal participation outcomes. This situation would still be just (according to Rawls and his difference principle) if they were to benefit from such an unequal arrangement. And this might be the case if we consider the vulnerable children's thoughts and suggestions on how they should be represented at school. Some of 98 
them (but not the majority) believe their voice is being represented and voiced through their representative. This representative (who expresses their opinions and addresses their needs makes the difference for the class community, unites the classroom, gathers all opinions and represents the wishes of all pupils in class, makes a complaint in their name etc.) is, it can be argued, elected in line with the difference principle because the least privileged children themselves believe they benefit from the maximised opportunities of the most privileged.

Interpreting just child participation in schools through a Rawlsian perspective is however not simple. Judging the child participation arrangement on the above postulate, we might assess it as being fair even though the most disadvantaged children are excluded. Yet, in practice, the majority of children's opinions differ when it comes to class representatives effectively representing their interests. The vulnerable group of children (and also other children) often express the view that the class representatives only represent their own interests and not the interests of the most vulnerable. As such, the views of the children in the worst position are not taken into account and hence their position cannot be improved by 'giving up' their representation to children in the best position. The difference principle is therefore not respected. Following this line of argument, the Rawlsian interpretation of what just child participation in school might be does not hold up.

For example, they talk about what to do in our school, what to introduce, what to eliminate. Nobody thinks about asking us what we need and even if a teacher tells them to ask us, they usually don't do that. They forget. So, for the most part only those who are in the child parliament choose. (Violica, 17 years, NGO I)

What often happens is that the topics discussed and agreements accepted in the forums are known only to the participants of forums, leaving other pupils not informed about them. Children see the main role of the representatives in providing them with feedback on discussions and conclusions from different school forums:

Because no one tells us anything. (Alexa, I2 years, elementary school 4)

Due to the most vulnerable children being unable to influence the participation agenda and because they do not receive sufficient feedback when they do, their motivation to participate rapidly decreases.

This sucks, it has no effect. (Matic, I2 years, elementary school 3) 
The view based on their own participation experience is that the participation arrangement at school is not an inclusive process. This deepens their impression that 'participation is not for them' and that the system is simply unfair; the result being, according to the focus group findings, the selective inclusion of children. Such results in turn often lead to vulnerable children adopting a strategy of retreat, mocking the participation process, and avoiding it in general.

In judging the fairness of the child participation arrangement in elementary schools according to the focus group findings, we may argue that the Rawlsian approach to assuring justice in such systems is limited. The children's views show that the universal opportunity to participate in participation activities does not (as an outcome) assure universal inclusion in them. In practice, the participation outcomes are unequal in spite of the systemic universality of child participation in schools. Further, no findings from the focus groups suggest that application of the difference principle to participation in schools would benefit the most vulnerable children - in the sense that the most vulnerable group of children would benefit from these unequal and unfair outcomes in child participation, which could make the argument for Rawlsian arrangement of child participation in schools fairer.

Arranging child participation in schools following the postulates of the recognition approach seems to be more just from the point of view of the most deprivileged. The recognition approach is softer and understands justice in more complex terms. Justice is not giving all children the same rights and then passively waiting to see what happens and hoping that on the mezzo system level an enthusiastic teacher will come along and manage to encourage vulnerable children to participate. Justice is giving all children the same participation rights and opportunities and then recognising that not all of them will be able to seize these new opportunities due to factors outside of their control (socio-economic, cultural, behavioural factors) representing their bivalent collectivity.

\section{Discussion and conclusion}

The article analyses injustice in the school environment based on Rawls' redistribution approach while further combining it with Fraser's recognition approach. The first approach enabled us to determinate indicators of just participation in elementary schools (mainly on the normative level of its regulation). Complementary to the first one, the second approach was used to help better understand why differences in participation among different groups of children occur in practice. 
If we try to project Rawls' ideas on justice (as elaborated in detail in the introductory part of the article) onto the participation of children in elementary schools, we must answer two questions:

a) Do all children have equal opportunities in participation processes? If the answer is yes, the following conditions must be met:

- access to information on participation is equal for all children (e.g., the topic of participation is part of the school curriculum);

- structures and mechanisms for participation in school are established;

- structures and mechanisms for participation in school are equally accessible to all children;

- every child can participate regardless of his/her gender, ethnic or cultural background; and

- resources for effective participation are equally distributed among all children; no group of children is deprivileged based on characteristics they have no control over.

b) Are the interests of the group of children which fails to participate despite the equal opportunities at least represented in participatory processes? To answer this question, a subjective assessment of vulnerable children can be very useful.

Based on the focus group analysis, we assess the participation in elementary schools in Slovenia as being unjust (regardless of the just normative regulation of participation). This finding relies on two arguments, first: participation is not just because the resources which enable children to participate are not equally distributed. The group of vulnerable children is less 'endowed' with resources like motivation, effort, good grades, exemplary behaviour, rhetorical skills and popularity (deemed necessary for effective participation) in comparison to the 'general population' of pupils. Rawls divides resources (or goods) into two groups: a) those which individuals have an influence over; and b) those which individuals cannot influence. As the resources needed for the successful participation of individuals also include those over which individuals have no influence, we claim that some children are inevitably and by default excluded from participation. In practice, it is simply impossible to divide between the resources children can influence and those they cannot because they more or less depend on the social context. The second argument: vulnerable children themselves stressed that their interests are not properly represented in the participation processes. They do not benefit from their participation being limited to sheer representation by others. 
On the other hand, Fraser understands justice in terms of struggles of bivalent collectivities for recognition and in doing so helps answer the following question: "Why do some groups of children fail to use their participation opportunities which are otherwise normatively granted universally to all?". Her approach redirects our attention from equality of opportunities to equality of outcomes:

- $\quad$ "Are there any differences in informedness among different groups of children? Why do such differences occur?"

- $\quad$ "Are there any differences in the accessibility of structures and mechanisms of participation in elementary schools among groups of children? Why do such differences occur?"

Fraser's approach points us in the direction of participation arrangements in practice. It defines gatekeepers who prevent realisation of the normative regulation of child participation in practice. Our analyses indicate that one of the most important gatekeepers preventing truly just child participations in elementary schools are the teachers who, according to the focus group participants, fail to understand that vulnerable children face barriers in participation which other children do not (ranging from a participation-unsupportive family environment, lack of capacities in terms of language, articulation of complex ideas, concepts, having good grades etc.). Therefore, to ensure more just participation, the list of resources needed for effective participation of children must be re-evaluated, especially if it is dominated by items over which children have no influence (natural primary goods). Just child participation should not be about 'suitability criteria' (eloquence, talents, intelligence, reliability, good grades, good behaviour etc.), which further reward the most advantaged in our society and therefore uphold the status quo by assuring that only one group of children 'calls the shots', but instead about recognising that some groups of children need more-than-equal participation opportunities. It is up to the education system to acknowledge this and establish more appropriate and just child participation measures in the future. What the education system should 'reward' and recognise in relation to child participation is precisely the sensitivity of children to injustice and the lack of recognition of children's moral status.

\section{References}

Boljka, U. (20rI) Univerzalni temeljni dohodek. Meje in možnosti njegove implementacije: Doctoral dissertation. Ljubljana: University of Ljubljana, Faculty of Social Sciences. 
Boljka, U., Rosič, J., Narat, T., Murgel, J., and Istenič, A. (2019) Implementing the child participation assessment tool in Slovenia. Ljubljana: Social Protection Institute of the Republic of Slovenia.

Boyatzis, R. E. (1998) Transforming qualitative information: Thematic analysis and code development. Thousand Oaks, CA: Sage.

Braun, V., and Clarke, V. (2006) Using thematic analysis in psychology. Qualitative Research in Psychology 3(2), pp. 77-101.

Brighouse, H. (2000) School choice and social justice. Oxford: Oxford University Press.

Brighouse, H. (2002) Egalitarian liberalism and justice in education. The Political Quarterly 73(2), pp. 18I-190.

Brighouse. H. (20II) Educational equality and school reform. In Haydon G. (ed.). Educational Equality, pp. 15-70. London: Continuum Intl Publishing Group.

Callan, E. (1997) Creating Citizens. Oxford: Clarendon Press.

Council of Europe (2016) Child Participation Assessment Tool. Retrieved from: https://www.coe.int/en/web/children/child-participation-assessment-tool (is July 2020).

Curren, R. (1995) Justice and the threshold of educational equality. Philosophy of Education, 1995/50.

Fargas Malet, M., McSherry, D., Larkin, E., and Robinskon, C. (2010) Research with children: Methodological issues and innovative techniques. Journal of Early Childhood Research 8(2), pp. 175-192.

Fraser, N. (1995) From redistribution to recognition? Dilemmas of Justice in a 'Postsocialist' Age. New Left Review 212 (July/August 1995), pp. II-I3.

Fraser, N. (2000) Rethinking recognition. New Left Review 3 (May-June 2000).

Fraser, N. (200I) Social justice in the knowledge society: Redistribution, recognition and participation. Congress "Gut zu Wissen”, Heinrich Boll-Stiftung, 5/200I.

Fraser, N. (2003) Social justice in the age of identity politics: Redistribution, recognition and participation. In Fraser, N., and Honneth, A. (ed.). Redistribution or Recognition? A Political-Philosophical Exchange, pp. 7-88. London: Verso.

Glaser, B., and Strauss, A. (1967) The discovery of grounded theory: Strategies for qualitative research. Chicago: Aldine. 
Harel Ben-Shahar, T. (2015) Equality in education - why we must go all the way. Ethical Theory and Moral Practice 19(I), pp. 83-100, Special Issue: Dimensions of Consequentialism.

Hart, A. R. (1992) Children's participation: From tokenism to citizenship. Firenze: UNICEF International Child Development Centre, Spedale degli Innocenti.

Hayes, N. (1997) Theory-led thematic analysis: Social identification in small companies. In Hayes, N. (ed.). Doing Qualitative Analysis in Psychology, pp. 93-II4. Hove, UK: Psychology Press.

Hennink, M., Kaiser N, B., and Weber, M. B. (2019) What influences saturation? Estimating sample sizes in focus group research. Qualitative Health Research 29(10), pp. I-I4.

Hill, M. (1997) Research review: Participatory research with children. Child and Family Social Work 2, pp. 17I-I83.

Kodele, T. (2017) Participacija učencev v procesu reševanja njihovih učnih težav. Doctoral dissertation. Ljubljana: Faculty of Education, University of Ljubljana.

Kodelja, Z. (2006) O pravičnosti vizobraževanju. Ljubljana: Ministrstvo za kulturo RS in Agencija za raziskovalno dejavnost RS.

Krek, J., and Metljak, M. (2011) Bela knjiga o vzgoji in izobraževanjuv Republiki Sloveniji. Ljubljana: Zavod RS za šolstvo.

Lansdown, G. (200I) Promoting children's participation in democratic decision-making. Firenze: United Nations Children's Fund. Innocenti Research Centre.

Marovič, M. (2017) Participacija otroka/mladostnika v vzgojnih zavodih. Doctoral dissertation. Koper: Faculty of Education, University of Primorska.

Mayall, B. (2000) The sociology of childhood in relation to children's rights. The International Journal of Children s Rights 8(3), pp. 243-259.

Mithans, M. (2017) Participacija učencev pri pouku in na šoli: doktorska disertacija. Maribor: Faculty of Education, University of Maribor.

O’Reilly, M., and Parker, N. (2013) 'Unsatisfactory saturation': A critical exploration of the notion of saturated samples sizes in qualitative research. Qualitative Research 13(2), pp. 190-197.

PISA, OECD (2020) What is PISA? Retrieved from: https://www.oecd.org/ pisa/ (I5 July 2020).

Rawls, J. (197I) A theory of justice. Cambridge: Harvard University Press.

Rawls, J. (1999) A theory of justice. Cambridge, Massachusetts: The Belknap Press of Harvard University Press. 
Rutar, S. (2014) Poti do participacije otrok v vzgoji. Koper: University of Primorska, Science and Research Centre, Scientific Publishing House Annales.

Saldana, J. (2012) The Coding Manual for Qualitative Researchers. London: Sage.

Strehar, K. (20II) Skupnost učencev šole in otroški parlament med idejo in prakso. Magistrsko delo. Ljubljana: Faculty of Education, University of Ljubljana.

Van Parijs, P. (2003) Hybrid justice, patriotism and democracy. A selective reply. In Reeve, A., and Williams, A. (eds.). Real Libertarianism Assessed. Political Theory after Van Parijs, pp. 201-216. Basingstoke: Palgrave Macmillan.

Veale, A. (2005) Creative methodologies in participatory research with children. In Greene, S., and Hogan D (ed.). Researching Children's Experience. Approaches and Methods, pp. 253-273. London: Sage Publications.

\section{Appendix}

Indicator 7: Children are provided with information about their right to participate in decision-making

I. What do you think are your rights?

2. Do you know that you have the right to express your opinion that your voice is heard and that you are taken seriously (at home, at school, in the local community, at the doctor's, at the CSW, in court...)?

3. How did you find out about these rights (were you told by teachers at school, parents, siblings, classmates, friends, anyone else)?

4. Did you learn about these rights in school? Did you perhaps learn anything about the topic of human rights at school? (In which subject?)

5. If these rights were explained to you, did you understand the explanation?

a. Do you think that child-friendly information on rights is accessible to all children - children of different ages and abilities (for example, children who cannot hear)?

b. Do you think that participation rights are equally accessible to children in large cities and small villages?

c. Do you think child-friendly information is available to vulnerable children (children in hospitals, youth prisons, detention centres, care facilities or asylum homes)? 
d. Do you think the rights are understandable to all children - both children in elementary and secondary school?

Indicator 8: Children are represented in forums, including through their own organisations, at school, on local, regional and national governance levels

I. Class president - how is he/she chosen (chosen by students or teachers, in what way)? Who is the most suitable/less suitable to be a class president?

2. Do you have a school parliament at your school? Do you have an opportunity to join the school parliament?

3. Do you have a children's municipal council in your municipality and do you have an opportunity to join it?

4. Can you participate in the regional children's parliament?

5. Can you participate in the state children's parliament?

- If YES: Do you think you have a significant influence on the decisions? Are your suggestions taken seriously?

- If NOT: Why do you think there is no children's parliament in your school or why do no children attend it?

- Are there certain groups of children who, in your opinion, are not members of organisations or do not participate in parliaments? Why not?

- How important do you think it is to have representatives of all children in the city/region/country in children's parliaments (forums)? (E.g. an equal number of boys and girls, children of different ages, children with different abilities including children with disabilities, children with different backgrounds (migrants, ethnic minorities, asylum-seekers). 